\title{
Performance Evaluation of Maize with Square Spacing for Maximizing the Yield Potential through Subsurface Drip Fertigation
}

\author{
M. Nagarajan ${ }^{1}$, S. Porpavai ${ }^{2}$, G. Thiyagarajan ${ }^{3^{*}}$ and M. Manikandan ${ }^{1}$ \\ ${ }^{1}$ (SWCE), Agricultural Engineering College and Research Institute, Tamil Nadu Agricultural \\ University, Kumulur - 621 712, India \\ ${ }^{2}$ Soil and Water Management Research Institute, Tamil Nadu Agricultural University, \\ Thanjavur - 613 501, India \\ ${ }^{3}$ (SWCE), Water Technology Centre, Tamil Nadu Agricultural University, \\ Coimbatore - 641 003, India \\ *Corresponding author
}

\begin{tabular}{|l|}
\hline Ke y w o r d s \\
$\begin{array}{l}\text { Crop water } \\
\text { requirement, } \\
\text { fertigation, Square } \\
\text { spacing, Subsurface } \\
\text { drip irrigation }\end{array}$ \\
\hline Article Info \\
\hline $\begin{array}{l}\text { Accepted: } \\
\text { 15 May } 2019 \\
\text { Available Online: } \\
\text { 10 June } 2019\end{array}$ \\
\hline
\end{tabular}

\section{Keywords}

Crop water requirement fertigation, Square spacing, Subsurface drip irrigation

Article Info

Accepted:

Available Online

June 2019

\section{A B S T R A C T}

There has been a growing gap between the demand for maize and its supply. One of the reasons often attributed to decline in maize productivity is poor production practices, awareness and characterized by low use of modern inputs. In order to avoid the lack of all the above to assess the current levels of technical efficiency of maize cultivation like spacing of Maize cultivation with effective management of irrigation practices could be taken as a study. The study was taken up for the cultivation of maize crop (variety of $\mathrm{Co} \mathrm{H}(\mathrm{M}) 6$ ) with main treatments of sub surface drip irrigation through calculated water requirement of crops (WRc) at $75 \%, 100 \% \& 125 \%$ and sub treatments of fertilizer application through fertigation at 50\%, $75 \%$ \& $100 \%$ of RDF. The irrigation was given in alternative days and the fertigation was given once in a week as per the schedule given in crop production guide. The inline emitter spacing is $40 \mathrm{~cm}$ and lateral spacing is $80 \mathrm{~cm}$ were considered for drip layout and paired row system was followed. The irrigation with $75 \%$ WRc consumed $338 \mathrm{~mm}$ of irrigation water and recorded lower yield of $5070 \mathrm{~kg} / \mathrm{ha}$ with the yield penalty of $31 \%$ (2300 $\mathrm{kg} / \mathrm{ha}$ ) when compared to $100 \%$ irrigation water. Similarly the irrigation with $125 \%$ consumed $529 \mathrm{~mm}$ of irrigation water and recorded the grain yield of $7343 \mathrm{~kg} / \mathrm{ha}$ with a reduction in yield of $250 \mathrm{~kg} / \mathrm{ha}$. The treatment $\mathrm{I}_{3} \mathrm{~F}_{1}(125 \% \mathrm{WRc}$ with $100 \%$ fertigation) was consumed higher quantity of irrigation water $(529 \mathrm{~mm})$ with lowest WUE $(9.28 \mathrm{~kg} / \mathrm{ha} \mathrm{mm})$ and water productivity $\left(0.93 \mathrm{~kg} / \mathrm{m}^{3} \&\right.$ Rs. $\left.129.83 \mathrm{ha} / \mathrm{mm}\right)$ when compared to other treatments. The treatment $\mathrm{I}_{2} \mathrm{~F}_{3}$ consumed $434 \mathrm{~mm}$ of irrigation water and recorded highest yield which saved 30 per cent of irrigation water when compared to control. In control the yield was 22 per cent significantly lowered when compared to $\mathrm{I}_{2} \mathrm{~F}_{3}$. The combination of Irrigation with $100 \% \mathrm{WRc}$ and $100 \%$ fertigation has given higher yield of $7670 \mathrm{~kg} / \mathrm{ha}$ when compared to reduced quantity of fertigation. 


\section{Introduction}

Maize is grown throughout the year in India. It is also known as all season crop. Maize is predominantly cultivated during kharif season with 85 per cent of the area under cultivation during this season. Maize is the third most important cereal crop in India after rice and wheat. It accounts for 9 per cent of total food grain production of the country. Maize production in India has grown at a CAGR (compound annual growth rate) of 5.5 per cent over the last ten years from 14 million tonnes in 2004-05 to 23 million tonnes in 2013-14 (FICCI, 2013). Factors such as adaptability to varied agro-climatic conditions, less labour, intensive and low water consuming crop which influence the yield and water consumption. Therefore in many areas, maize becomes alternate crop to rice which resulted in increase in area under maize cultivation.

Irrigation plays a paramount role in increasing the productivity of crops and enhancing the cropping intensity. Apart from benefiting the farmers, irrigation development also helps to increase the employment opportunities and wage rate of agricultural labourers. However, water is becoming increasingly scarce in Tamil Nadu due to increased industrialization and intensive agriculture. With the fast decline of irrigation water potential and continued expansion of population and economic activity in many parts of the State the problems of water scarcity is expected to be aggravated further. Sivanappan (2004) stated that using micro irrigation for various crops saves water upto 40-70 percent besides yield increase.

Fertigation is one such technology where water-soluble fertilizer or chemical can be applied in precise amounts in synchrony with the plant needs, directly into the root zone of the crop. This not only economizes the water use, but also improves nutrient use efficiency, as the fertilizer applied remains confined to the root zone of the crop. Information on the moisture and nutrient distribution under fertigation is rather scanty. While considering from the nutrient point of view, this system would be considered essential, though the vegetable - based system would be profitable (Ramesh, 2002). Drip irrigation holds promise in this respect (Narda and Lubana, 1999). Drip fertigation permits application of nutrients directly at the site of high concentration of active roots (Sivanappan et. al., 1987).

Maize (Zea mays L.) is an important cereal crop of India and plays pivotal role in agricultural economy both as staple food for larger section of population, raw materials for industries and feed for animals. With intention of achieving evergreen revolution, intensive research in maize has been started anticipating its importance for food and feed.

In India maize is grown in an area of 6.2 $\mathrm{m}$. ha, with a production of $10.57 \mathrm{~m} . \mathrm{t}$ and the average productivity is $1700 \mathrm{~kg} \mathrm{ha}^{-1}$ (Anon, 2003). The present annual requirement of grain maize for different purposes is $12 \mathrm{~m} . \mathrm{t}$ of which 4.5 m.t for poultry (Sounderarajan, 2002) with a gap of 1.5 m.t. In Tamil Nadu, maize is cultivated in an area of 0.20 m.ha. with a production of 0.24 m.t. with an average productivity of $1189 \mathrm{~kg} \mathrm{ha}^{-1}$ (Anon, 2006). By $2020 \mathrm{AD}$, the requirement of maize for various sectors will be around 100 m.t, of which the poultry sector demand alone will be around 31m.t. (Seshaiah, 2000).

\section{Materials and Methods}

The main focus of this project was to initiate maize crop in NCDZ (New Cauvery Delta Zone) as alternative cropping system for rice especially during summer which consume less quantity of irrigation water. 
Summer 2016 \& 2017

Season: Summer (2016 - 2017)

Crop: Maize

Crop spacing: 40 x $40 \mathrm{~cm}$ (Square spacing)

Design: split plot

Replications: 3

\section{Treatments}

The treatment consists of three irrigation regimes in main plots and three fertilizer levels in sub plots.

\section{Main Plot: Irrigation regimes}

$\mathrm{I}_{1}$ - Drip irrigation at $75 \%$ calculated water requirement of crops (WRc)

$\mathrm{I}_{2}$ - Drip irrigation at $100 \%$ calculated water requirement of crops (WRc)

$\mathrm{I}_{3}$ - Drip irrigation at $125 \%$ calculated water requirement of crops (WRc)

\section{Design data for drip}

Lateral pipe size - $16 \mathrm{~mm}$

Spacing between the lateral pipe $-80 \mathrm{~cm}$

Emitter type - Inline emitter

Spacing between the emitter $-40 \mathrm{~cm}$

Sub plots: Fertilizer levels

$\mathrm{F}_{1}-50 \%$ Recommended dose of fertilizer through drip irrigation

$\mathrm{F}_{2}-75 \%$ Recommended dose of fertilizer through drip irrigation

$\mathrm{F}_{3}-100 \%$ Recommended dose of fertilizer through drip irrigation

(The RDF of Maize $=150: 75: 75 \mathrm{~kg}$ NPK ha 1)

\section{Comparison treatment}

One control treatment with conventional ridges and furrow irrigation on IW/CPE ratio 1.0 and the soil application of 100 per cent recommended dose of fertilizer was included for comparison.

\section{Summer 2016 \& 2017}

The details of study for both the year of summer $2016 \& 2017$ are given below. The second crop of summer 2017 experiment was conducted (variety of Co H(M) 6) with main treatments of sub surface drip irrigation through calculated water requirement of crops (WRc) at $75 \%, 100 \% \& 125 \%$ and sub treatments of fertilizer application through fertigation at $50 \%, 75 \%$ \& $100 \%$ of RDF. The irrigation was given in alternative days and the fertigation was given once in a week as per the schedule given in crop production guide.

\section{Square Spacing effect}

The inline emitter spacing is $40 \mathrm{~cm}$ and lateral spacing is $80 \mathrm{~cm}$ were considered for drip layout and paired row system was followed. The emitter is located in the centre of crop which could distribute the water for 4 crops as shown in Figure 1.

As per the location of emitter every crop could receive the water from two numbers of emitter accordingly.

\section{Study of moisture distribution pattern under drip irrigation}

The moisture distribution pattern of subsurface drip irrigation was studied under different irrigation schedules viz., 75\%, 100\% and $125 \%$ of calculated crop water requirement (WRc) of maize. The WRc is calculated using the below formula; 
WR / plant $=$ PE $x$ Pc $\mathrm{X}$ Kc $\mathrm{x}$ wetting percentage $(80 \%)$

Where,

$\mathrm{WR}=$ Water Requirement in $\mathrm{mm}$

$\mathrm{PE}=$ Pan Evaporation in $\mathrm{mm}$

Pc. $=$ Pan Co-efficient

$\mathrm{Kc}=$ Crop Co-efficient

According to the irrigation schedule the movement of water in soil from the drip irrigation was studied. For this study the soil sample was collected from both sides of the emitter from the surface in vertical and horizontal direction after application of the measured quantity of water calculated through the above equation. Totally 15 samples (each side 6 samples and centre on the emitter 3 samples) were collected and the soil moisture (in percentage) was estimated through volumetric analysis. The soil moisture study was conducted in three different locations of each irrigation schedule, the average moisture in each irrigation schedule was plotted in the surfer 8.0 software

\section{Effect of drip fertigation on growth and yield of maize}

The second crop of summer 2016 experiment was conducted (same variety) by the revised main treatments of sub surface drip irrigation through calculated water requirement of crops (WRc) at $75 \%, 100 \%$ \& $125 \%$ and sub treatments of fertilizer application through fertigation at $50 \%, 75 \% \& 100 \%$ of RDF. The irrigation was given in alternative days and the fertigation was given once in a week as per the schedule given in TNAU crop production guide.

\section{Effect of sub surface drip irrigation on water saving}

The irrigation was scheduled according the calculated irrigation water requirement viz.,
$75 \%, 100 \%$ and $125 \%$ and the irrigation was given once in alternative days. The two days cumulative pan evaporation data was collected from meteorological station, SWMRI, Thanjavur and calculated the WRc and irrigation was given accordingly.

The Water Use Efficiency (WUE) and water productivity are calculated by the below formula.

WUE $=($ Total yield $(\mathrm{kg} / \mathrm{ha})) /($ Total irrigation water used (mm)) x 100

Water productivity $=$ Yield $(\mathrm{kg}) /$ Volume of irrigation water used $\left(\mathrm{m}^{3}\right)$

(Or)

Water productivity $=$ Total income $($ in Rs./ha) / (Total irrigation water used (mm)

\section{Effect of fertigation on fertilizer saving}

The fertilizer was given on weekly basis through venture system. The quantity of fertilizer $\mathrm{N}, \mathrm{P} \& \mathrm{~K}$ was calculated and followed the fertiligation schedule from TNAU crop production guide. The Fertilizer Use Efficiency (FUE) for $\mathrm{N}, \mathrm{P} \& \mathrm{~K}$ were calculated by the below formula;

FUE $=($ Total fertilizer used $(\mathrm{Kg} / \mathrm{ha})) /($ Yield $(\mathrm{Kg} / \mathrm{ha})) \times 100$

\section{Economics}

The total cost of cultivation was calculated on every individual treatments and gross income is accounted both yield and the residual of stubbles. B: C ratio of every treatment was calculated separately using the below formula.

B: $\mathrm{C}$ ratio $=$ Total gross income (Rs.) $/$ Cost of cultivation (Rs.) 


\section{Pooled data analysis}

Comparative studies of two years pooling (Summer 2016 \& 2017) data viz., yield, WUE \& water productivity of subsurface drip irrigation were analyzed and found the variation of every individual treatments.

\section{Results and Discussions}

\section{Study of moisture distribution pattern}

The soil moisture study was conducted in three different locations of each irrigation schedule, the average moisture in each irrigation schedule was plotted in the surfer 8.0 software as shown in Fig. $2,3 \& 4$.

In $75 \%$ of WRc the percentage of moisture varied from 17.2 to $24 \%$ and it was found that the centre of emitter the highest percentage of moisture (24\%) was obtained. The moisture pattern was linearly varied from centre to both sides of emitter up to $20 \mathrm{~min}$ both horizontal and vertical directions as depicted in Fig. 2.

Similarly in $100 \% \mathrm{WRc}$, the percentage of moisture was varied from the maximum of $26 \%$ to the minimum of $18.3 \%$. The linear movement of moisture around the emitter is evenly ranged with approximately $1 \%$ deviation in all the directions from the centre of the emitter as shown in Fig.3. Hence, the lateral and vertical movement of moisture is almost equal in range with respect to the horizontal and vertical directions.

Whereas the $125 \% \mathrm{WRc}$, the percentage of moisture was distributed from 22.8 to $28 \%$ where the highest percentage of moisture was obtained in the exact location of emitter. The distribution of moisture in one side (right side) is higher $(1.5 \%$ more) than other side due to the rapid flow of water in one side as shown in Fig. 4. Similar trends of results were found by Ali et al., (2010) and Isoda et al., (2007). Hence, the study revealed that moisture distribution in all the directions from the emitter is spatially varied in all the irrigation schedules. $100 \% \mathrm{WRc}$ is found to have optimal distribution of moisture when compared with others.

\section{Effect of drip fertigation on growth and yield of maize}

The results revealed that, in summer 2016 the study of sub surface drip fertigation on the production of maize were observed and given in Table 1. The highest plant height (158.4 $\mathrm{cm}$ ) was obtained in treatment $\mathrm{I}_{2} \mathrm{~F}_{3}$ (Irrigation at $100 \%$ WRC with $100 \% \mathrm{RDF}$ ) followed by $\mathrm{I}_{3} \mathrm{~F}_{3}(156.4 \mathrm{~cm})$ and the lowest height was recorded $(107.2 \mathrm{~cm})$ in $\mathrm{I}_{1} \mathrm{~F}_{1}$ (applying irrigation at $75 \% \mathrm{WRc}$ with $50 \% \mathrm{RDF}$ ).

It was found that increasing and decreasing water and fertigation stress was significantly resulted in a decrease of plant height.

There is also a significant effects were observed from No. of grains/cobs and 1000 grains weight as shown in Table 1 . Reduced amount of irrigation also caused reduced number of grains with lesser weight, counting to be the highest numbers of grains and weight of 1000 grain in treatment $\mathrm{I}_{2} \mathrm{~F}_{3}(310$ \& $21.80 \mathrm{gm})$, followed by $\mathrm{I}_{3} \mathrm{~F}_{3}(292 \& 21.60$ gm) and the least was recorded in treatment $\mathrm{I}_{1} \mathrm{~F}_{1}(155 \& 16.80 \mathrm{gm})$.

The same way the cob length and girth found to be highest in $\mathrm{I}_{2} \mathrm{~F}_{3}(23.67 \& 18.33 \mathrm{~cm})$, followed by treatment $\mathrm{I}_{3} \mathrm{~F}_{3}(22.94 \& 17.17$ $\mathrm{cm})$ and the least was recorded in $\mathrm{I}_{1} \mathrm{~F}_{1}(19.33$ \& $14.07 \mathrm{~cm}$ ), whereas the control has recorded $22.47 \& 16.66 \mathrm{~cm}$.

The results revealed that, in summer 2017 the study of sub surface drip fertigation on the production of maize were observed and given 
in Table 1. The highest plant height (198.7 $\mathrm{cm}$ ) was obtained in treatment $\mathrm{I}_{2} \mathrm{~F}_{3}$ (Irrigation at $100 \% \mathrm{WRc}$ with $100 \% \mathrm{RDF}$ ) followed by $\mathrm{I}_{3} \mathrm{~F}_{3} \& \mathrm{I}_{2} \mathrm{~F}_{2}(196 \mathrm{~cm})$ and the lowest height was recorded $(182.7 \mathrm{~cm})$ in $\mathrm{I}_{1} \mathrm{~F}_{1}$ (applying irrigation at $75 \% \mathrm{WRc}$ with $50 \% \mathrm{RDF})$. It was found that increasing and decreasing water and fertigation stress was significantly resulted in a decrease of plant height.

There is also a significant effects were observed from No. of grains/cobs and 1000 grains weight as shown in Table 1. Reduced amount of irrigation and fertigation also caused reduced number of grains with lesser weight, counting to be the highest numbers of grains and 1000 grain weight is in treatment $\mathrm{I}_{2} \mathrm{~F}_{3}$ (306 \& $143.6 \mathrm{gm}$ ), followed by $\mathrm{I}_{3} \mathrm{~F}_{3}$ $(295.6 \& 141.2 \mathrm{gm})$ and the least was recorded in treatment $\mathrm{I}_{1} \mathrm{~F}_{1}(222.4 \& 118.1$ $\mathrm{gm})$, whereas the control was recorded 250.1 $\& 130.3 \mathrm{gm}$.

The same way the cob length and girth found to be highest in $\mathrm{I}_{2} \mathrm{~F}_{3}(26.2 \& 17.4 \mathrm{~cm})$, followed by treatment $\mathrm{I}_{3} \mathrm{~F}_{3}(25.8 \& 16.1 \mathrm{~cm})$ and the least was recorded in $\mathrm{I}_{1} \mathrm{~F}_{1}(22.9 \&$ $13.3 \mathrm{~cm})$.

Table.1 Influence of treatments on crop growth parameters (2016 \& 2017)

\begin{tabular}{|c|c|c|c|c|c|c|c|c|c|c|}
\hline \multirow[t]{2}{*}{ Treatments } & \multicolumn{5}{|c|}{ Summer 2016} & \multicolumn{5}{|c|}{ Summer 2017} \\
\hline & $\begin{array}{c}\text { Pl. } \\
\text { height } \\
\text { (cm) }\end{array}$ & $\begin{array}{c}\text { Cob } \\
\text { length } \\
\text { (cm) }\end{array}$ & $\begin{array}{l}\text { Cob } \\
\text { girth } \\
\text { (cm) }\end{array}$ & $\begin{array}{c}\text { No. of } \\
\text { grains/ } \\
\text { cob }\end{array}$ & $\begin{array}{c}100 \\
\text { grains } \\
\text { wt } \\
(\mathrm{gm})\end{array}$ & $\begin{array}{c}\text { Pl. } \\
\text { height } \\
\text { (cm) }\end{array}$ & $\begin{array}{c}\text { Cob } \\
\text { length } \\
\text { (cm) }\end{array}$ & $\begin{array}{l}\text { Cob } \\
\text { girth } \\
\text { (cm) }\end{array}$ & $\begin{array}{l}\text { No. of } \\
\text { grains } \\
\text { / cob }\end{array}$ & $\begin{array}{c}100 \\
\text { grains } \\
\text { wt }(\mathrm{gm})\end{array}$ \\
\hline $\mathbf{I}_{1} \mathbf{F}_{1}$ & 107.2 & 19.3 & 14.1 & 155 & 16.8 & 182.7 & 22.9 & 13.3 & 222 & 118.1 \\
\hline $\mathbf{I}_{1} \mathbf{F}_{2}$ & 121.2 & 19.3 & 15.1 & 195 & 17.4 & 188.9 & 24.6 & 14.7 & 235 & 126.0 \\
\hline $\mathbf{I}_{1} \mathbf{F}_{3}$ & 132.1 & 19.5 & 15.3 & 207 & 18.9 & 194.3 & 25.4 & 15.8 & 238 & 129.4 \\
\hline $\mathbf{I}_{2} \mathbf{F}_{1}$ & 115.0 & 20.0 & 15.0 & 175 & 17.2 & 187.4 & 23.2 & 14.1 & 230 & 119.9 \\
\hline $\mathbf{I}_{2} \mathbf{F}_{2}$ & 134.3 & 21.1 & 17.5 & 224 & 17.9 & 196.1 & 25.1 & 16.1 & 258 & 131.6 \\
\hline $\mathbf{I}_{2} \mathbf{F}_{3}$ & 158.4 & 23.7 & 18.3 & 310 & 21.8 & 198.7 & 26.2 & 17.4 & 306 & 143.6 \\
\hline $\mathbf{I}_{3} \mathbf{F}_{1}$ & 120.9 & 20.7 & 15.2 & 177 & 17.5 & 188.6 & 23.1 & 14.4 & 229 & 121.1 \\
\hline $\mathbf{I}_{3} \mathbf{F}_{2}$ & 133.0 & 21.2 & 16.7 & 252 & 19.2 & 195.5 & 25.0 & 15.3 & 263 & 134.5 \\
\hline $\mathbf{I}_{3} \mathbf{F}_{3}$ & 156.4 & 22.9 & 17.2 & 292 & 21.6 & 196.4 & 25.8 & 16.1 & 295 & 141.2 \\
\hline Control & 145.2 & 22.5 & 16.7 & 270 & 20.8 & 194.5 & 24.3 & 16.1 & 250 & 130.3 \\
\hline
\end{tabular}


Table.2 Yield, WUE and Water Productivity during summer 2016

\begin{tabular}{|c|c|c|c|c|c|c|c|}
\hline $\begin{array}{l}\text { Treatmen } \\
\text { ts }\end{array}$ & $\begin{array}{l}\text { Yield } \\
\text { kg/ha }\end{array}$ & $\begin{array}{l}\text { Water } \\
\text { used } \\
(\mathbf{m m})\end{array}$ & $\begin{array}{l}\text { Rainfall \& } \\
\text { Eff. Rainfall } \\
(\mathrm{mm})\end{array}$ & $\begin{array}{l}\text { Total } \\
\text { water used } \\
(\mathrm{mm})\end{array}$ & $\begin{array}{l}\text { WUE } \\
\text { Kg/ha } \\
\text { \& mm) }\end{array}$ & $\begin{array}{c}\text { Water } \\
\text { productivit } \\
y \text { in } \mathrm{kg} / \mathrm{m}^{3}\end{array}$ & $\begin{array}{c}\text { Water } \\
\text { productivity } \\
\text { (Rs./ha \& mm) }\end{array}$ \\
\hline $\mathbf{I}_{1} \mathbf{F}_{1}$ & 4484 & \multirow{3}{*}{266} & \multirow{10}{*}{$\begin{array}{c}85.8 \\
\& \\
42.9\end{array}$} & 308.9 & 14.52 & 1.45 & 203.2 \\
\hline $\mathbf{I}_{1} \mathbf{F}_{2}$ & 5604 & & & 308.9 & 18.14 & 1.81 & 253.9 \\
\hline $\mathbf{I}_{1} \mathbf{F}_{3}$ & 5780 & & & 308.9 & 18.71 & 1.87 & 261.9 \\
\hline $\mathbf{I}_{2} \mathbf{F}_{1}$ & 4584 & \multirow{3}{*}{354} & & 369.9 & 12.39 & 1.24 & 161.6 \\
\hline $\mathbf{I}_{2} \mathbf{F}_{2}$ & 6514 & & & 369.9 & 16.41 & 1.64 & 229.7 \\
\hline $\mathbf{I}_{2} \mathbf{F}_{3}$ & 7436 & & & 369.9 & 18.74 & 1.87 & 262.2 \\
\hline $\mathbf{I}_{3} \mathbf{F}_{1}$ & 4525 & \multirow{3}{*}{443} & & 485.9 & 09.31 & 0.93 & 130.3 \\
\hline $\mathbf{I}_{3} \mathbf{F}_{2}$ & 6588 & & & 485.9 & 13.56 & 1.36 & 189.8 \\
\hline $\mathbf{I}_{3} \mathbf{F}_{3}$ & 7287 & & & 485.9 & 15.00 & 1.50 & 209.9 \\
\hline Control & 6637 & 450 & & 492.9 & 13.47 & 1.34 & 188.5 \\
\hline
\end{tabular}

\begin{tabular}{|l|l|l|l|}
\hline & & SED & CD (0.05) \\
\hline $\mathbf{i}$ & $\longrightarrow$ & 4.55 & 12.66 \\
\hline $\mathbf{f}$ & $\longrightarrow$ & 5.84 & 12.73 \\
\hline $\mathbf{i}$ at f & $\longrightarrow$ & 9.43 & 21.87 \\
\hline $\mathbf{f ~ a t ~ i ~}$ & $\longrightarrow$ & 10.12 & 22.05 \\
\hline & & & \\
\hline
\end{tabular}

Table.3 Yield, WUE and Water Productivity during summer 2017

\begin{tabular}{|c|c|c|c|c|c|c|c|}
\hline $\begin{array}{l}\text { Treatme } \\
\text { nts }\end{array}$ & $\begin{array}{l}\text { Yield } \\
\mathrm{kg} / \mathrm{ha}\end{array}$ & $\begin{array}{l}\text { Water } \\
\text { used } \\
(\mathbf{m m})\end{array}$ & $\begin{array}{l}\text { Rainfall \& } \\
\text { Eff. Rainfall } \\
\text { (mm) }\end{array}$ & $\begin{array}{l}\text { Total } \\
\text { water used } \\
(\mathbf{m m})\end{array}$ & $\begin{array}{l}\text { WUE } \\
\text { Kg/ha/ } \\
\text { mm) }\end{array}$ & $\begin{array}{c}\text { Water } \\
\text { productivit } \\
\mathrm{y} \text { in } \mathrm{kg} / \mathrm{m}^{3}\end{array}$ & $\begin{array}{c}\text { Water } \\
\text { productivity } \\
\text { (Rs./ha mm) }\end{array}$ \\
\hline $\mathbf{I}_{1} \mathbf{F}_{1}$ & 4695 & \multirow{3}{*}{312} & \multirow{10}{*}{$\begin{array}{c}52 \\
\& \\
26 \\
\text { ainy days) }\end{array}$} & 338 & 13.89 & 1.39 & 171.17 \\
\hline $\mathbf{I}_{1} \mathbf{F}_{2}$ & 5195 & & & 338 & 15.37 & 1.54 & 189.40 \\
\hline $\mathbf{I}_{\mathbf{1}} \mathbf{F}_{3}$ & 5330 & & & 338 & 15.77 & 1.58 & 194.32 \\
\hline $\mathbf{I}_{2} \mathbf{F}_{1}$ & 4818 & \multirow{3}{*}{408} & & 434 & 11.10 & 1.11 & 155.42 \\
\hline $\mathbf{I}_{2} \mathbf{F}_{2}$ & 5335 & & & 434 & 12.29 & 1.23 & 172.10 \\
\hline $\mathbf{I}_{2} \mathbf{F}_{3}$ & 7670 & & & 434 & 17.67 & 1.77 & 247.42 \\
\hline $\mathbf{I}_{3} \mathbf{F}_{1}$ & 4908 & \multirow{3}{*}{503} & & 529 & 9.28 & 0.93 & 129.89 \\
\hline $\mathbf{I}_{3} \mathbf{F}_{2}$ & 5635 & & & 529 & 10.65 & 1.07 & 149.13 \\
\hline $\mathbf{I}_{3} \mathbf{F}_{3}$ & 7343 & & & 529 & 13.88 & 1.39 & 194.33 \\
\hline Control & 6283 & 540 & & 566 & 11.10 & 1.11 & 166.28 \\
\hline
\end{tabular}

\begin{tabular}{|l|l|l|l|}
\hline & & SED & CD (0.05) \\
\hline I & $\longrightarrow$ & 21.22 & 58.99 \\
\hline F & $\longrightarrow$ & 27.22 & 59.27 \\
\hline i at f & $\longrightarrow$ & 43.93 & 101.86 \\
\hline f at i & $\longrightarrow$ & 47.12 & 102.67 \\
\hline
\end{tabular}


Table.4 FUE and cost economics during summer 2016

\begin{tabular}{|c|c|c|c|c|c|c|c|c|c|}
\hline \multirow[t]{2}{*}{$\begin{array}{l}\text { Treatme } \\
\text { nts }\end{array}$} & \multicolumn{3}{|c|}{$\begin{array}{l}\text { Total fertilizer } \\
\text { used (kg/ha) }\end{array}$} & \multicolumn{3}{|c|}{ FUE } & \multirow{2}{*}{$\begin{array}{l}\text { Cost of } \\
\text { cultivation } \\
\text { (Rs.) }\end{array}$} & \multirow{2}{*}{$\begin{array}{l}\text { Gross } \\
\text { Income } \\
\text { (Rs.) }\end{array}$} & \multirow[t]{2}{*}{$\begin{array}{l}\text { B.C. } \\
\text { ratio }\end{array}$} \\
\hline & $\mathrm{N}$ & $\mathrm{P}$ & $\mathrm{K}$ & $\mathrm{N}$ & $P$ & $\mathrm{~K}$ & & & \\
\hline $\mathbf{I}_{1} \mathbf{F}_{1}$ & 75 & 38 & 38 & 59.79 & 118.00 & 118.00 & 62700 & 62776 & 1.00 \\
\hline $\mathbf{I}_{1} \mathbf{F}_{2}$ & 113 & 56 & 56 & 49.59 & 100.07 & 100.07 & 64500 & 78456 & 1.22 \\
\hline $\mathbf{I}_{\mathbf{1}} \mathbf{F}_{\mathbf{3}}$ & 150 & 75 & 75 & 38.53 & 077.07 & 077.07 & 66000 & 80920 & 1.23 \\
\hline $\mathbf{I}_{2} \mathbf{F}_{1}$ & 75 & 38 & 38 & 61.12 & 120.63 & 120.63 & 62700 & 68376 & 1.02 \\
\hline $\mathbf{I}_{2} \mathbf{F}_{2}$ & 113 & 56 & 56 & 57.65 & 116.32 & 116.32 & 64500 & 91196 & 1.41 \\
\hline $\mathbf{I}_{2} \mathbf{F}_{3}$ & 150 & 75 & 75 & 49.57 & 099.15 & 099.15 & 66000 & 104104 & 1.58 \\
\hline $\mathbf{I}_{3} \mathbf{F}_{1}$ & 75 & 38 & 38 & 60.33 & 119.08 & 119.08 & 62700 & 68950 & 1.01 \\
\hline $\mathbf{I}_{3} \mathbf{F}_{2}$ & 113 & 56 & 56 & 58.30 & 117.64 & 117.64 & 64500 & 92232 & 1.43 \\
\hline $\mathbf{I}_{3} \mathbf{F}_{3}$ & 150 & 75 & 75 & 48.58 & 097.16 & 097.16 & 66000 & 102018 & 1.55 \\
\hline Control & 250 & 75 & 75 & 26.55 & 088.49 & 088.49 & 45000 & 92918 & 2.11 \\
\hline
\end{tabular}

Table.5 FUE and cost economics during summer 2017

\begin{tabular}{|c|c|c|c|c|c|c|c|c|c|}
\hline \multirow[t]{2}{*}{$\begin{array}{l}\text { Treatme } \\
\text { nts }\end{array}$} & \multicolumn{3}{|c|}{$\begin{array}{l}\text { Total fertilizer } \\
\text { used (kg/ha) }\end{array}$} & \multicolumn{3}{|c|}{ FUE } & \multirow{2}{*}{$\begin{array}{l}\text { Cost of } \\
\text { cultivation } \\
\text { (Rs.) }\end{array}$} & \multirow{2}{*}{\begin{tabular}{|l|} 
Gross \\
Income \\
(Rs.)
\end{tabular}} & \multirow[t]{2}{*}{$\begin{array}{l}\text { B.C. } \\
\text { ratio }\end{array}$} \\
\hline & $\mathrm{N}$ & $P$ & $\mathrm{~K}$ & $\mathrm{~N}$ & $\mathrm{P}$ & K & & & \\
\hline $\mathbf{I}_{1} \mathbf{F}_{1}$ & 75 & 38 & 38 & 62.60 & 123.55 & 123.55 & 62700 & 65730 & 1.05 \\
\hline $\mathbf{I}_{1} \mathbf{F}_{2}$ & 113 & 56 & 56 & 45.97 & 92.77 & 92.77 & 64500 & 72730 & 1.13 \\
\hline $\mathbf{I}_{1} \mathbf{F}_{3}$ & 150 & 75 & 75 & 35.53 & 71.07 & 71.07 & 66000 & 74620 & 1.13 \\
\hline $\mathbf{I}_{2} \mathbf{F}_{1}$ & 75 & 38 & 38 & 64.24 & 126.79 & 126.79 & 62700 & 67452 & 1.08 \\
\hline $\mathbf{I}_{2} \mathbf{F}_{2}$ & 113 & 56 & 56 & 47.21 & 95.27 & 95.27 & 64500 & 74690 & 1.16 \\
\hline $\mathbf{I}_{2} \mathbf{F}_{3}$ & 150 & 75 & 75 & 51.13 & 102.27 & 102.27 & 66000 & 107380 & 1.63 \\
\hline $\mathbf{I}_{3} \mathbf{F}_{1}$ & 75 & 38 & 38 & 65.44 & 129.16 & 129.16 & 62700 & 68712 & 1.10 \\
\hline $\mathbf{I}_{3} \mathbf{F}_{2}$ & 113 & 56 & 56 & 49.87 & 100.63 & 100.63 & 64500 & 78890 & 1.22 \\
\hline $\mathbf{I}_{3} \mathbf{F}_{3}$ & 150 & 75 & 75 & 48.95 & 97.91 & 97.91 & 66000 & 102802 & 1.56 \\
\hline Control & 250 & 75 & 75 & 25.13 & 83.77 & 83.77 & 45000 & 87962 & 1.95 \\
\hline
\end{tabular}


Fig.1 Layout of Crop cultivation under subsurface drip irrigation

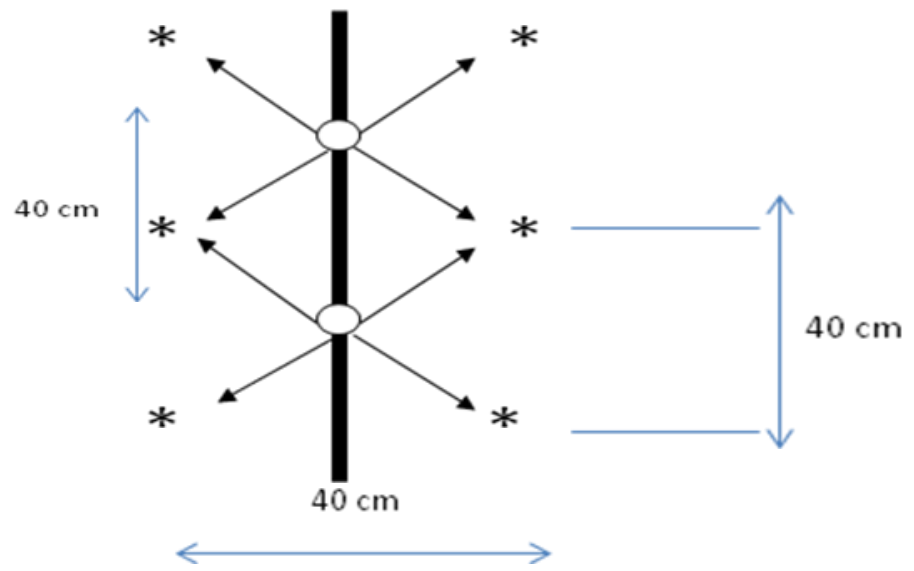

Fig.2 Moisture distribution pattern at 75\% WRc

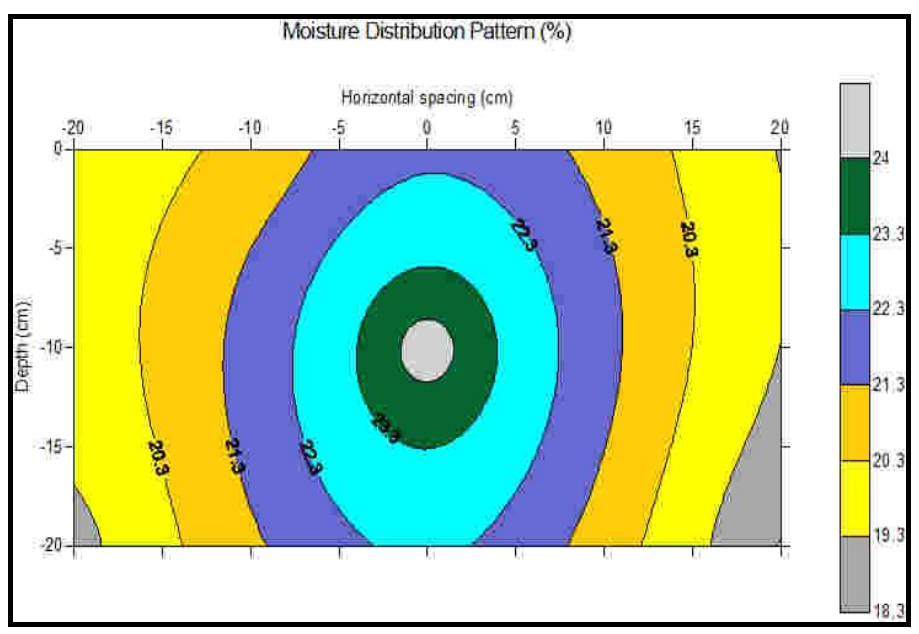

Fig.3 Moisture distribution pattern at 100\% WRc




Fig.4 Moisture distribution pattern at 125\% WRc

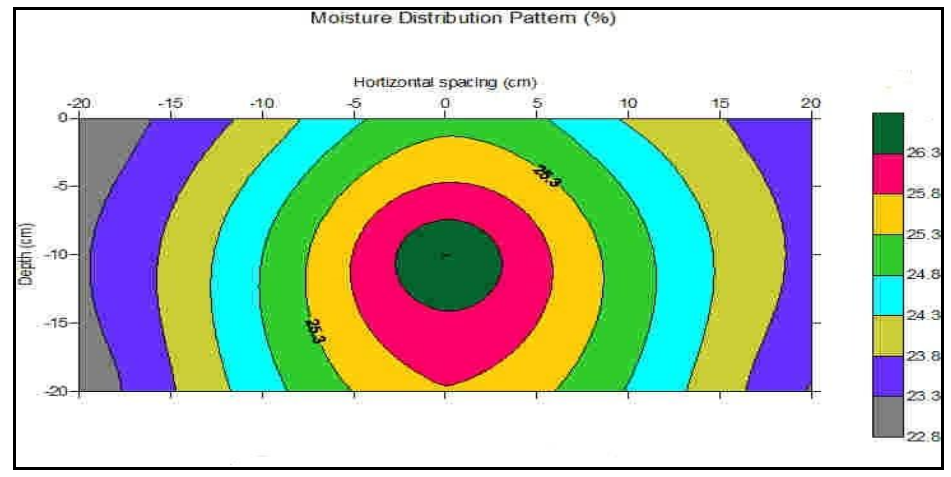

Fig.5 Comparative performance of yield difference during summer 2016-2017

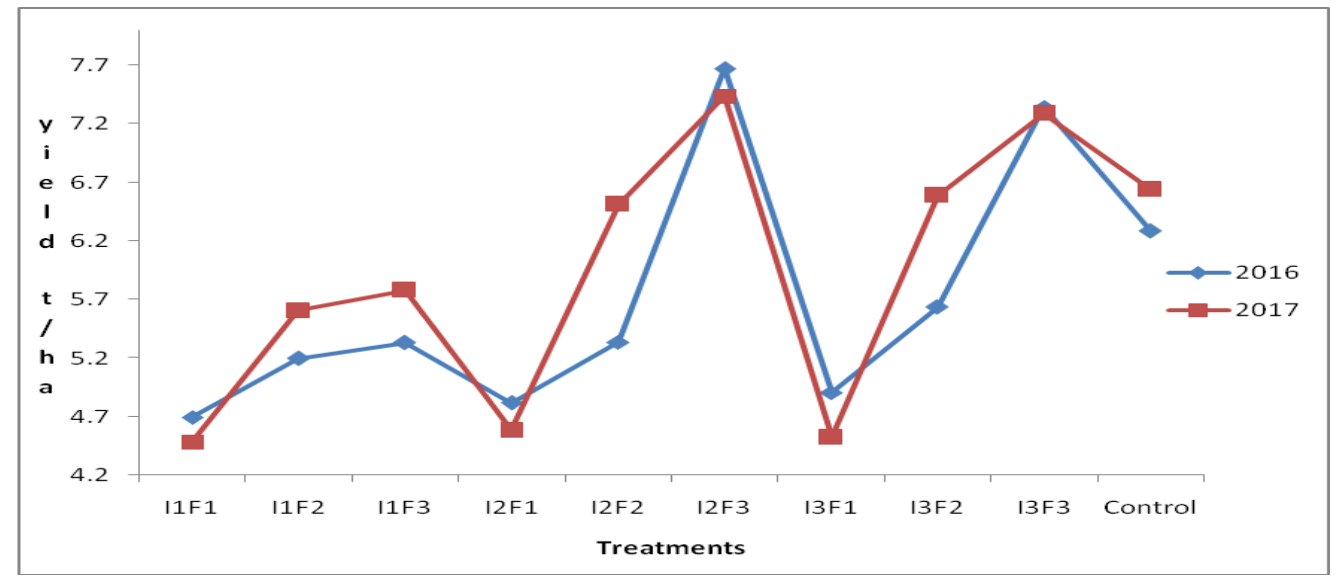

\section{Effect of sub surface drip irrigation on water saving}

During summer 2016 the highest WUE (18.74 $\mathrm{kg} / \mathrm{ha} \mathrm{mm}$ ) was recorded in treatment $\mathrm{I}_{2} \mathrm{~F}_{3}$ consumed $370 \mathrm{~mm}$ in 30 Nos of irrigations. Of irrigations produced significantly higher grain yield of $7436 \mathrm{~kg} / \mathrm{ha}$ as depicted in Table 2. The second highest WUE $(18.71 \mathrm{~kg} / \mathrm{ha}$ $\mathrm{mm}$ ) recorded in treatment $\mathrm{I}_{1} \mathrm{~F}_{3}$ which also received 30 Nos. of irrigations consumed only $266 \mathrm{~mm}$ of irrigation water and recorded lower grain yield of $5780 \mathrm{~kg} / \mathrm{ha}$. Further the treatments $\mathrm{I}_{3} \mathrm{~F}_{1}, \mathrm{I}_{2} \mathrm{~F}_{1} \& \mathrm{I}_{1} \mathrm{~F}_{1}$ recorded lesser WUE $(09.31,12.39 \& 14.52 \mathrm{~kg} / \mathrm{ha} \mathrm{mm})$ and observed significantly lower grain yield of $4525,4584 \& 4484 \mathrm{~kg} / \mathrm{ha}$ respectively and consumed more quantity of water. The sub surface drip irrigation with all the treatments of WR were saved 24\% (approx. $100 \mathrm{~mm}$ ) of irrigation when compared to conventional as practiced by IW/CPE ratio consumed $493 \mathrm{~mm}$ of water (9 Nos. of irrigation) which is significantly higher amount of water (Approx. $100 \mathrm{~mm}$ ) when compared to subsurface drip irrigation and the grain yield of $6637 \mathrm{~kg} / \mathrm{ha} \&$ WUE were recorded $6697 \mathrm{~kg} / \mathrm{ha} \& 13.47$ $\mathrm{kg} / \mathrm{ha} \mathrm{mm}$. Similarly the highest water productivity $\left(1.87 \mathrm{~kg} / \mathrm{m}^{3} \& 262.3 \mathrm{Rs} / \mathrm{ha} \mathrm{mm}\right)$ was recorded in treatment $\mathrm{I}_{2} \mathrm{~F}_{3}$ and the least was observed in $\mathrm{I}_{3} \mathrm{~F}_{1}\left(0.93 \mathrm{~kg} / \mathrm{m}^{3} \& 130.38\right.$ Rs/ha mm.

During summer 2017 the highest WUE (17.67 $\mathrm{kg} / \mathrm{ha} \mathrm{mm}$ ) was recorded in treatment $\mathrm{I}_{2} \mathrm{~F}_{3}$ consumed $434 \mathrm{~mm}$ of irrigations water in 34 Nos. of irrigations significantly higher grain yield of $7670 \mathrm{~kg} / \mathrm{ha}$ as depicted in Table 3 . 
This was followed by treatment $\mathrm{I}_{1} \mathrm{~F}_{3} \& \mathrm{I}_{1} \mathrm{~F}_{2}$ which also received 34 Nos. of irrigations consumed only $338 \mathrm{~mm}$ of irrigation water and recorded a significantly lower grain yield of $5330 \& 5195 \mathrm{~kg} / \mathrm{ha}$ with the WUE of 15.77 \& $15.37 \mathrm{~kg} / \mathrm{ha} \mathrm{mm}$. Further the treatments $\mathrm{I}_{3} \mathrm{~F}_{1}, \mathrm{I}_{3} \mathrm{~F}_{2}, \mathrm{I}_{2} \mathrm{~F}_{1} \& \mathrm{I}_{2} \mathrm{~F}_{2}$ recorded lesser WUE $(09.28,10.65,11.10 \& 12.29 \mathrm{~kg} / \mathrm{ha} \mathrm{mm})$ and observed significantly lower grain yield of $4908,5635,4818 \& 5335 \mathrm{~kg} / \mathrm{ha}$ respectively. The sub surface drip irrigation with all the treatments of WRc were saved $25 \%$ (approx. $120 \mathrm{~mm}$ ) of irrigation when compared to conventional method was practiced by IW/CPE ratio consumed $566 \mathrm{~mm}$ of water (10 Nos. of irrigation) with $11.10 \mathrm{~kg} / \mathrm{ha} \mathrm{mm}$ of WUE which is significantly higher amount of water (Approx. $120 \mathrm{~mm}$ ) when compared to subsurface drip irrigation and obtained grain yield of $6283 \mathrm{~kg} / \mathrm{ha}$. Similar results were found by Yadav et al., (2004), Clark et al., 1999, Cassel et al., 2001 and Dalvi, 1999.

Similarly the highest water productivity (1.77 $\mathrm{kg} / \mathrm{m}^{3}$ \& $247.42 \mathrm{Rs} . / \mathrm{ha} / \mathrm{mm}$ ) was recorded in treatment $\mathrm{I}_{2} \mathrm{~F}_{3}$ followed by $\mathrm{I}_{1} \mathrm{~F}_{2}, \mathrm{I}_{1} \mathrm{~F}_{3} \& \mathrm{I}_{3} \mathrm{~F}_{3}$ $\left(1.54 \& 1.58 \mathrm{~kg} / \mathrm{m}^{3}\right.$ and $189.40 \& 194.32$ Rs./ha mm) and the least was observed in $\mathrm{I}_{3} \mathrm{~F}_{1}$ $\left(0.93 \mathrm{~kg} / \mathrm{m}^{3}\right)$, whereas the control was obtained $1.11 \mathrm{~kg} / \mathrm{m}^{3}$.

\section{Effect of fertigation on fertilizer saving}

Fertigation offers various advantages such as: easy application of amount and concentration of nutrients suited to the crop according to its stage of development; reduces the salinization and groundwater pollution; decreases fluctuation in nutrient concentration in soil during the crop growing season; permits easy use of soluble solid as well as balanced liquid fertilizer and micronutrients (Bar-Yosef, 1999). Efficient fertigation scheduling requires attention to three factors: crop specific nutrient requirements, timely nutrient delivery to meet the crop needs and controlling irrigation to minimize leaching of soluble nutrients below the effective root zone (Hochmuth and Hanlon, 1995). In summer 2016 the highest FUE of N, P \& K (61.1, $120.6 \& 120.6)$ was found to be in treatment $\mathrm{I}_{2} \mathrm{~F}_{1} \& \mathrm{I}_{3} \mathrm{~F}_{1}$, followed by $\mathrm{I}_{1} \mathrm{~F}_{1}(59.79,118.00 \&$ 118.00) and least was recorded in $\mathrm{I}_{1} \mathrm{~F}_{3}(38.53$, $77.07 \& 77.03)$ respectively, whereas the control has observed significantly lower FUE of 26.5, 88.4 \& 88.4 due to manual application of fertilizer as presented in Table 4.

In Summer 2017 the highest FUE of N, P \& K $(65.44,129.16 \& 129.16)$ was found to be in treatment $\mathrm{I}_{3} \mathrm{~F}_{1}$ followed by $\mathrm{I}_{2} \mathrm{~F}_{1}(64.24,126.79$ \& 126.79) and least was recorded in $\mathrm{I}_{1} \mathrm{~F}_{3}$ (35.53, 71.07 \& 71.07) respectively. The higher FUE were observed from 50\% \& $75 \%$ RDF which consumed minimum fertilizer and applied through fertigation, whereas the control has observed significantly lower FUE of $25.13,83.77 \& 83.77$ due to manual application of fertilizer as presented in Table 5.

Similar trend of results have been documented by Imamsaheb et al., (2014). Similarly increased yield under drip ferigation were reported by Tumbare et al., (1999) and Tumbare, A.D. and Nikam, D.R. (2004).

\section{Economics}

In summer 2016 the control has the highest B.C ratio of 2.11 with yield of $6637 \mathrm{~kg} / \mathrm{ha}$, since the control was taken without drip irrigation cost. Treatment $\left(\mathrm{I}_{3} \mathrm{~F}_{2}\right)$ with $100 \%$ irrigation with $100 \%$ recommended fertilizer obtained the maximum yield of $7436 \mathrm{~kg} / \mathrm{ha}$, besides the highest B.C ratio of 2.11 when compared with other treatments (shown in Table 4). This was followed by treatment $\mathrm{I}_{3} \mathrm{~F}_{3}$ with B.C ratio of 1.55 and the least B.C ratio was found to be in treatment $\mathrm{I}_{1} \mathrm{~F}_{1}(75 \% \mathrm{WRc}$ $\& 50 \%$ recommended fertilizer) of 1.00 . 
In summer 2017 the control has the highest B.C ratio of 1.95 with yield of $6283 \mathrm{~kg} / \mathrm{ha}$, since the control was taken up without drip irrigation cost. Among the drip irrigation treatment $\left(\mathrm{I}_{3} \mathrm{~F}_{2}\right)$ with $100 \%$ irrigation with $100 \%$ recommended fertilizer obtained maximum yield of $7670 \mathrm{~kg} / \mathrm{ha}$, besides the highest B.C ratio of 1.63 when compared with other treatments (shown in Table 5). This was followed by treatment $\mathrm{I}_{3} \mathrm{~F}_{3}$ with B.C ratio of 1.56 and the least B.C ratio was found to be in treatment $\quad \mathrm{I}_{1} \mathrm{~F}_{1} \quad(75 \% \quad \mathrm{WRc} \quad \& \quad 50 \%$ recommended fertilizer) of 1.05 .

\section{Pooled data analysis}

Comparative studies of two years pooling (Summer $2016 \&$ 2017) data of subsurface drip irrigation were also analyzed and depicted in Fig. 5. The highest average yield $(7553 \mathrm{~kg} / \mathrm{ha})$ and WUE $(18.20 \mathrm{~kg} / \mathrm{ha} \mathrm{mm})$ was obtained in treatment $\mathrm{I}_{2} \mathrm{~F}_{3}(100 \% \mathrm{WRc}$ with $100 \%$ fertigation) followed by treatment $\mathrm{I}_{3} \mathrm{~F}_{3}(125 \%$ WRc with $100 \%$ fertigation). The lowest yield was observed on treatment $\mathrm{I}_{1} \mathrm{~F}_{1}$ (75 \% WRc with 50\% RDF) (Avg. 4590 $\mathrm{kg} / \mathrm{ha}$ ) for both the years. Though the highest yield was recorded in (treatment $\mathrm{I}_{2} \mathrm{~F}_{3}$ ) $100 \%$ WRc with $100 \%$ fertigation, the FUE is comparatively lesser with other treatments due to higher consumption of fertilizer through fertigation which is contrary indicating quite higher consumption of fertilizer when compared to $F_{1} \& F_{2}$. The treatment $\mathrm{I}_{3} \mathrm{~F}_{1} \quad(125 \%$ WRc with $100 \%$ fertigation) was consumed higher quantity of irrigation water $(529 \mathrm{~mm})$ with lowest WUE $(9.28 \mathrm{~kg} / \mathrm{ha} \mathrm{mm})$ and water productivity $(0.93$ $\mathrm{kg} / \mathrm{m}^{3}$ \& Rs. 129.83 ha mm) when compared to other treatments. The treatment $\mathrm{I}_{2} \mathrm{~F}_{3}$ consumed $434 \mathrm{~mm}$ of irrigation water and recorded highest yield which was saved 30 per cent of irrigation water when compared to control. In control the yield was 22 per cent significantly lowered when compared to $\mathrm{I}_{2} \mathrm{~F}_{3}$, The irrigation with $75 \%$ and $125 \%$ were observed reduced plant height, cob length, cob girth, no. of grains / cob, 1000 grain weight, etc., were found to be increasing and decreasing stress.

In conclusions, the irrigation with $75 \%$ WRc consumed $338 \mathrm{~mm}$ of irrigation water and recorded lower yield of $5070 \mathrm{~kg} / \mathrm{ha}$ (avg.) with the yield penalty of $31 \%$ (avg. 2300 $\mathrm{kg} / \mathrm{ha}$ ) when compared to $100 \%$ irrigation water. Similarly the irrigation with $125 \%$ consumed $529 \mathrm{~mm}$ of irrigation water and recorded the grain yield of $7343 \mathrm{~kg} / \mathrm{ha}$ with a reduction in yield of $250 \mathrm{~kg} / \mathrm{ha}$. The treatment $\mathrm{I}_{3} \mathrm{~F}_{1}$ (125\% WRc with $100 \%$ fertigation) was consumed higher quantity of irrigation water $(529 \mathrm{~mm})$ with lowest WUE $(9.28 \mathrm{~kg} / \mathrm{ha} \mathrm{mm})$ and water productivity $\left(0.93 \mathrm{~kg} / \mathrm{m}^{3}\right.$ \& Rs. $129.83 \mathrm{ha} / \mathrm{mm}$ ) when compared to other treatments. The treatment $\mathrm{I}_{2} \mathrm{~F}_{3}$ consumed 434 $\mathrm{mm}$ of irrigation water and recorded highest yield which saved 30 per cent of irrigation water when compared to control. In control the yield was 22 per cent significantly lowered when compared to $\mathrm{I}_{2} \mathrm{~F}_{3}$. The combination of Irrigation with $100 \%$ WRc and $100 \%$ fertigation has given higher yield of $7670 \mathrm{~kg} / \mathrm{ha}$ when compared to reduced quantity of fertigation.

\section{References}

Ali, M.H., Shahram, A. and Simon, B. 2010. Evaluation of the influence of irrigation methods and water quality on sugar beet yield and water use efficiency. J. Agric. Water Mgmt., 97(2): 357- 362.

Anon., 2003. Agriculture Production; FAO STAT Agriculture Data. www.fao.org. html.

Anon., 2006. Season and crop report of Tamil Nadu (2005-2006), Department of Economics and Statistics, Chennai - 600 006.

B.Bar-Yosef, 1999. Advances in Fertigation. Published in Science direct, Elsevier, vol. 65, 1999, 1-77. 
Cassel, Sharmasarker F.S., Sharmasarkar, S.D., Miller, Vance, G.F. and Zhang, R. 2001. Assessment of drip and flood irrigation on water and fertilizer use efficiencies for sugarbeets. J. Agric. Water Mgmt., 46 (3): 241-251.

Clark, G.A., Stanley, C.D., Maynard, D.N., Hochmuth, G.J., Hanlon, E.A. and Haman, D.Z. 1999. Water and fertilizer management of micro irrigated fresh market tomatoes. Trans. ASAE, 34(2): 429-435.

Dalvi, V.B., Tiwari, K.N., Pawade, M.N. and Phire, P.S. 1999. Response surface analysis of tomato production under micro irrigation. J. Water Mgmt., 41 (1): 11-19.

FICCI, 2013. Maize vision 2022. A knowledge report. FICCI organized first India Maize Summit in 2013.

Hochmuth, G. J., and E. Hanlon. 1995. IFAS standardized fertilization recommendations for vegetable crops. Fla. Coop. Ext. Serv. Circ. 1152.

Imamsaheb, S.J., C.N. Hanchinmani and K. Ravinaik 2014. Impact of drip irrigation and fertigation on growth, yield, quality and economic returns in different vegetable crops. The Asian Journal of Horticulture, vol.9, Issue 2; Dec. 2014; 484-491.

Isoda, A., Konishi, H., Wu, Wang-Pei and Yuan, Li-Zhi 2007. Effects of different irrigation methods on yield and water use efficiency of sugar beet in the arid area of China. Agric. Water Mgmt., 61(2): 7-10.

Narda, N.K. and S.P. Lubana. 1999. Growth dynamics studies of tomatoes under subsurface drip irrigation. J. Res. Punjab Agric. Univ., 36(3-4): 222-233.
Ramesh, G. 2002. Biologically efficient and profitable cropping system for garden lands of western agro-climatic zone of Tamil Nadu. Ph.D., Thesis submitted to Tamil Nadu Agricultural University, Coimbatore.

Seshaiah, M.P. 2000. Sorghum grain in poultry feed. In. Technical and Institutional options for sorghum grain mould management. Proc. In H. Consultation. Chandhrasekaran, A., R. Bandyopadhyay and H.I. Hall (Eds.). ICRISAT, Patencheru, Andhra Pradesh, India. 18 - 19 May, 2000; pp.240-241.

Sivanappan, R.K, O. Padmakumari and V. Kumar. 1987. Drip Irrigation. Keerthi Publishing House, Coimbatore, India, pp. 75-80.

Sivanappan, R.K. 2004. Efficient storage methods. The Hindu Survey of Indian Agriculture, pp $135-137$.

Sounderarajan, B., 2002. Duty free import of maize sought. The Hindu, $31^{\text {st }}$ May, 2002. Prentice Hall. Inc. Englewood Cliff NJ.

Tumbare, A.D. and Nikam, D.R. 2004. Effect of planting and fertigation on growth and yield of green chilli (Capsicum annuum L.). Indian J. Agric. Sci., 74(5): 242-245.

Tumbare, A.D., Shinde, B.N. and Bhoite, B.U. 1999. Effect of liquid fertilizers through drip irrigation on growth of yield of okra. Indian J. Agron., 44(1): 176-178.

Yadav, A.C., Singh, Avatar, Baswana, K.S., Sharma, N.K. and Dahiya, M.S. 2004. Effect of various irrigation and fertility levels on the production of newly developed brinjal cultivars. Haryana J. Hort. Sci., 3(3\&4): 284-286.

\section{How to cite this article:}

Nagarajan, M., S. Porpavai, G. Thiyagarajan and Manikandan, M. 2019. Performance Evaluation of Maize with Square Spacing for Maximizing the Yield Potential through Subsurface Drip Fertigation. Int.J.Curr.Microbiol.App.Sci. 8(06): 1808-1820.

doi: https://doi.org/10.20546/ijcmas.2019.806.216 